\title{
Synergistic tumor inhibition of colon cancer cells by nitazoxanide and obeticholic acid, a farnesoid $\mathrm{X}$ receptor ligand
}

\author{
Junhui Yu ${ }^{1} \cdot$ Kui Yang ${ }^{1} \cdot$ Jianbao Zheng $^{1} \cdot$ Wei Zhao ${ }^{1} \cdot$ Xuejun Sun $\mathbb{D}^{1}$ \\ Received: 5 May 2020 / Revised: 24 August 2020 / Accepted: 22 September 2020 / Published online: 13 October 2020 \\ (c) The Author(s) 2020. This article is published with open access, corrected publication 2021
}

\begin{abstract}
The tumor-suppressive role of Farnesoid X receptor (FXR) in colorectal tumorigenesis supports restoring FXR expression as a novel therapeutic strategy. However, the complicated signaling network and tumor heterogeneity hinder the effectiveness of FXR agonists in the clinical setting. These difficulties highlight the importance of identifying drug combinations with potency and specificity to enhance the antitumor effects of FXR agonists. In this study, we found that the $\beta$-catenin level affected the antitumor effects of the FXR agonist OCA on colon cancer cells. Mechanistic studies identified a novel FXR/ $\beta$-catenin complex in colon cancer cells. Furthermore, the depletion of $\beta$-catenin expedited FXR nuclear localization and enhanced its occupancy of the SHP promoter and thereby sensitized colon cancer cells to OCA. Furthermore, we utilized a drug combination study and identified that the antiparasitic drug nitazoxanide (NTZ) abrogated $\beta$-catenin expression and acted synergistically with OCA in colon cancer cells. The combination of OCA plus NTZ exerts synergistic tumor inhibition in CRC both in vitro and in vivo by cooperatively upregulating SHP expression. In conclusion, our study offers useful evidence for the clinical use of FXR agonists combined with $\beta$-catenin inhibitors in combating CRC.
\end{abstract}

\section{Introduction}

Colorectal cancer (CRC) is the second most common cause of cancer-related death [1]. Globally, approximately $1,800,000$ new cases are diagnosed as CRC every year. Due to distant metastasis and relapse, most advanced-stage of $\mathrm{CRC}$ has a poor prognosis $[2,3]$. The five-year survival rate of stage I CRC patients exceeds $90 \%$; however, the fiveyear survival rate of stage IV CRC patients is slightly higher than $10 \%$ [4]. An increasing number of genetic and molecular alterations have been recognized in colorectal

These authors contributed equally: Junhui Yu, Kui Yang

Supplementary information The online version of this article (https:// doi.org/10.1038/s41417-020-00239-8) contains supplementary material, which is available to authorized users.

$\triangle$ Wei Zhao

zhaowei9803@126.com

$\triangle$ Xuejun Sun

sunxy@mail.xjtu.edu.cn

1 Department of General Surgery, First Affiliated Hospital of Xi'an Jiaotong University, 277 West Yanta Road, 710061 Xi' an, China carcinogenesis, including genetic mutations, microsatellite instability, and DNA hypermethylation [5].

Canonical Wnt/ $\beta$-catenin signaling plays a vital role in colorectal tumorigenesis [6]. Persistent activation of Wnt signaling is characterized by nuclear accumulation of $\beta$-catenin [7]. $\beta$-Catenin can be stabilized in approximately $75 \%$ of CRC patients by inactivating mutations in APC, and in an additional $5 \%$ of patients by phosphodegron mutations in $\beta$-catenin [8]. These mutations facilitate the occurrence of microadenoma, whereas other mutations, including KRAS, p53, and SMAD4 mutations, contribute to a malignant transition from microadenoma to larger adenomas and adenocarcinomas [9]. Targeting the $\mathrm{Wnt} / \beta$-catenin pathway is supposed to be a rational therapeutic strategy for CRC [10]. However, to date, no anticancer drugs targeting this signaling pathway have advanced to clinical applications. Porcupine inhibitors and tankyrase inhibitors exert inhibitory effects on Wnt signaling upstream of the $\beta$-catenin destruction complex [11], and are therefore unlikely to effectively fight against $\beta$-catenin in CRC with the most frequent mutations (APC or $\beta$-catenin mutations) [12]. Recently, the antiparasitic drug nitazoxanide (NTZ), approved by the US Food and Drug Administration (FDA) for use in humans, has been reported to antagonize $\mathrm{Wnt} / \beta$-catenin signaling by abrogating 
$\beta$-catenin independent of GSK-3 $\beta$ and APC [13], indicating the potential therapeutic value of NTZ in APC-mutated or $\beta$-catenin-mutated CRC.

Farnesoid X receptor (FXR, encoded by NR1H4), a bile acid-activated nuclear receptor, regulates the homeostasis of lipid, cholesterol and glucose metabolism [14]. Mounting evidence supports a pivotal role for FXR in colorectal tumorigenesis. Diminished FXR is significantly related to late tumor stage and often predicts a poor prognosis [15]. Loss of FXR promoted intestinal inflammation and colon tumorigenesis [16]. Conversely, activation of intestinal FXR can suppress abnormal cell growth and curtail CRC progression [17]. Thus, targeting FXR and restoring its function might be an attractive tactic for CRC treatment.

Obeticholic acid (OCA) is a novel FXR agonist and a derivative of chenodeoxycholic acid (CDCA) and shows almost 100-fold greater potency than CDCA [18]. Importantly, OCA has been approved by the FDA for the treatment of primary biliary cholangitis [19]. Recent studies indicate that OCA shows a promising antitumor effect in cholangiocarcinoma [20] and HCC [21]. However, the complicated signaling network and tumor heterogeneity might hinder the effectiveness of FXR agonists in cancer treatment [22]. This highlights the importance of identifying drug combinations or novel chemicals with potency and specificity to enhance the antitumor effects of FXR activation. Herein, our study aimed to explore the antitumor effect of OCA in CRC and further identify a potential target to rationally design a combinational approach based on an FXR agonist to combat CRC.

\section{Materials and methods}

\section{Cell cultures}

Colon cancer cells SW403, SW480, DLD-1, HT-29, HCT116, and RKO (Shanghai Institute of Cell Biology, Chinese Academy of Sciences) were all routinely cultured in DMEM (Gibco BRL, Carlsbad, CA, USA) supplemented with $10 \%$ fetal bovine serum (Gibco BRL, Carlsbad, CA, USA) at $5 \% \mathrm{CO}_{2}$ at $37{ }^{\circ} \mathrm{C}$. Once the cell confluence reaches $70 \%$, they were treated with various doses of OCA (Sellerk, Houston, TX, USA) for $48 \mathrm{~h}$ in the presence or absence of NZT (Sellerk, Houston, TX, USA). For ICG-001, cells were incubated in the presence of ICG-001 $(10 \mu \mathrm{M}$, Sellerk, Houston, TX, USA) for $24 \mathrm{~h}$ along with OCA. OCA ( $5 \mathrm{mg}$ ) was reconstituted in $1.1887 \mathrm{~mL}$ DMSO to $10 \mathrm{mM}$. NTZ $(5 \mathrm{mg})$ was reconstituted in $1.6272 \mathrm{~mL}$ DMSO to $10 \mathrm{mM}$. The final concentration of DMSO in control and experimental groups was maintained at less than $0.1 \%$ in all treatments.

\section{Lentiviral vectors and transfection}

The phU6-EGFP-shRNA-FXR and phU6-EGFP-shRNA$\beta$-catenin lentiviral vectors and their control vectors were commercially purchased from GeneChem Co., Ltd. (Shanghai, China). The transfection process is completed in accordance with the manufacturer's instructions.

\section{Drug combination studies}

For in vitro experiment, Cells per well were seeded in the 96-well plates at a density of $3 \times 10^{3}$. The following day, the cells were treated with a single compound or with a combination of OCA and NTZ for $48 \mathrm{~h}$. CCK8 kit was used to measure cell viability. Combination index (CI) and fraction affected $(\mathrm{Fa})$ values were calculated using CompuSyn software. $\mathrm{CI}>1, \mathrm{CI}=1$, and $\mathrm{CI}<1$ indicate antagonism, addictive and synergy effect respectively.

For in vivo experiment, $Q$ value method of Zhengjun jin was adopted [23]. $Q$ value $>1.15$ was synergistic; $0.85-1.15$ was additive; $<0.85$ was antagonistic.

\section{CCK8, colony formation, cell cycle, and apoptosis assays}

For CCK8 assay, cells were seeded into 96-well culture plates at 3000 cells/well for $48 \mathrm{~h}$. Cell viability was checked by CCK- 8 assay according to manufacturer's protocol. Normalization was done to cells treated with DMSO as vehicle, which were defined as $100 \%$. For colony formation assay, three hundred cells were seeded and cultured for 14 days. Colonies ( $\geq 50$ cells/colony) were counted. For cell cycle determination, cells were seeded at a density of $1 \times$ $10^{5}$ cells/well in 6-well plates. Cells were collected and fixed in $75 \%$ freezing ethanol and kept overnight at $4{ }^{\circ} \mathrm{C}$. After digesting with RNase A for $30 \mathrm{~min}$ at $37^{\circ} \mathrm{C}$, the cells were incubated with propidium iodide for $30 \mathrm{~min}$ shielded from light. The cell cycle was evaluated with flow cytometry (BD, Franklin Lakes, NJ, USA). For apoptosis assay, cells were seeded at a density of $1 \times 10^{5}$ cells/well in 6-well plates. Cells were labeled with Annexin V PE/7-AAD (BD Biosciences, Franklin Lakes, NJ, USA) according to the manufacturer's protocol as previously described [24]. Each experiment was performed in triplicate.

\section{Transwell assays}

Cell invasion was measured by using Transwell inserts (Corning, New York, NY, USA) with Matrigel (BD, Franklin Lakes, NJ, USA). The under chamber was filled with $600 \mu \mathrm{L}$ of RPMI 1640 medium added with $20 \%$ FBS. The upper chamber filters were precoated with $50 \mu \mathrm{L}$ of Matrigel and plated at $1 \times 10^{5}$ cells per upper chamber. 
The cells were incubated at $37{ }^{\circ} \mathrm{C}$ for $48 \mathrm{~h}$. After incubation, cells not through the aperturs on the upper surface of the Transwell inserts were got rid of with fresh PBS. The migratory or invading cells on the underside of the membrane were fixed with $4 \%$ paraformaldehyde and dyed with $1 \%$ crystal violet. The number of cells was counted in three randomly selected fields of fixed cells under an inverted microscope. Each experiment was repeated three times.

\section{Nude mouse xenograft assay}

All animal experiments were conducted in line with the institutional guidelines, and was authorized by the Institutional Animal Care and Use Committee of the First Affiliated Hospital of Xi'an Jiaotong University. The female BALB/c-nude mice (5-week-old) were purchased from a corporation of Shanghai (SLAC Laboratory Animal Co, China). The mice were injected with $5 \times 10^{6}$ colon cancer cells into the right flanks to construct xenograft tumor mice model. Once the size of xenograft tumors reached approximately $100 \mathrm{~mm}^{3}$, the nude mice were randomly divided into four subgroups and were administered by oral gavage of OCA $(10 \mathrm{mg} / \mathrm{kg} /$ day $)$ and NTZ $(200 \mathrm{mg} / \mathrm{kg} /$ day $)$ alone or in combination for consecutive 18 days. Tumor size was monitored using callipers every 3 days, and the tumor volume was measured the according to the formula $\left(a \times b^{2} \times 0.5, a\right.$ : length, $b$ : width). After 18 days of drug administration, the mice were executed and the xenograft tumors were isolated and weighted.

\section{RNA isolation and real-time PCR}

TRIzol $^{\circledR}$ reagent (Invitrogen; Thermo Fisher Scientific, Inc.) was employed to extract total RNA from cells in accordance with the manufacturer's instructions. The PrimeScript ${ }^{\circledR}$ RT Reagent kit (Takara Biotechnology Co., Ltd., Dalian, China) was employed to reverse transcription in the condition of $37^{\circ} \mathrm{C}$ for $15 \mathrm{~min}$ and $85^{\circ} \mathrm{C}$ for $5 \mathrm{~s}$, followed by reserved at $4{ }^{\circ} \mathrm{C}$. Real-time PCR was performed using SYBR Premix Ex Taq II (Takara Biotechnology Co., Ltd.) on a PCR Detection system (CFX96 ${ }^{\mathrm{TM}}$, Bio-Rad Laboratories, Inc., Hercules, CA, USA). The qRT-PCR condition adopted two-step method: pre-denaturation at $95^{\circ} \mathrm{C}$ for $30 \mathrm{~s}$ followed by forty cycles of denaturation at $95{ }^{\circ} \mathrm{C}$ for $5 \mathrm{~s}$ and extension at $60^{\circ} \mathrm{C}$ for $1 \mathrm{~min}$. The relative mRNA expression level was analyzed by using the $2^{-\Delta \Delta \mathrm{Cq}}$ method [25]. The sequences of primers were summarized in Supplementary Table S1. Each experiment was repeated three times.

\section{Immunohistochemistry (IHC)}

Fresh tissues were quickly fixed with $10 \%$ neutral formalin at room temperature overnight and embedded in paraffin.
Afterwards, 4- $\mu \mathrm{m}$ tissue slides were prepared. The standard Streptavidin-Biotin Complex (SABC) method was adopted to perform IHC staining procedure. Primary antibodies were employed in the slides with the concentration of $1: 100$ overnight at $4{ }^{\circ} \mathrm{C}$, and then biotinylated secondary antibody (Wuhan Boster Biological Technology, Ltd., Wuhan, China) was employed for $30 \mathrm{~min}$ at $37^{\circ} \mathrm{C}$. The images were collected by using a Nikon ECLIPSE Ti-S microscope mounted with a Nikon digital camera (Nikon Corporation), and all specimens were independently evaluated by two researchers.

\section{Total protein extraction and Western blot}

The cells were lysed with RIPA buffer containing containing a protease inhibitor cocktail on ice for $40 \mathrm{~min}$. The BCA method (Pierce; Thermo Fisher Scientific, Inc.) was used to quantify each sample. Separate the protein by SDS-PAGE and transfer the protein to activated polyvinylidene difluoride membranes. Following 5\% skim milk, the membranes were incubated with primary antibodies followed by incubation with horseradish peroxidase (HRP)-conjugated secondary antibodies. The visualized signals of the bands were acquired by exposing to Chemiluminescent HRP Substrate (Millipore, Billerica, MA, USA) via protein imprinting imaging system and the protein expression was analyzed using Image software (National Institutes of Health, Bethesda, MD, USA). The detailed information regarding these antibodies was presented in Supplementary Table S2. Each experiment was repeated three times.

\section{Immunofluorescence (IF)}

Cells were fixed with $4 \%$ paraformaldehyde for $20 \mathrm{~min}$, and then punched with $0.2 \%$ Triton X-100 for 10 min. Block cells with $5 \%$ bovine serum albumin at room temperature for $30 \mathrm{~min}$, and then incubate cells with primary antibody (anti-FXR with 1:100 dilution) at $4{ }^{\circ} \mathrm{C}$ overnight. The sections were washed three times with PBS for $10 \mathrm{~min}$ each time, and then incubated with Alexa Fluor 594-conjugated secondary antibody (1:400 dilution, Invitrogen, Carlsbad, CA, USA) for $1 \mathrm{~h}$ at room temperature and protected from light. The nucleus was stained with DAPI for $10 \mathrm{~min}$. Finally, the sample was observed using a fluorescence microscope (Leica Microsystems, Heidelberg, Germany) to analyze the subcellular localization of FXR. Each experiment was repeated three times.

\section{Immunoprecipitation (IP) assay}

After fresh cells were washed three times with cold PBS, they were collected by IP lysis. The bait protein antibody 
(anti-FXR antibody) is cross-linked with Amino-Link plus coupling resin (Pierce Co-IP kit, Rockford, IL, USA) at room temperature for $1-2 \mathrm{~h}$ according to the method of the manufacturer's instructions. About $500 \mu \mathrm{g}$ of protein lysate was added to resin-antibody complex and was shook slowly at $4{ }^{\circ} \mathrm{C}$ overnight. After the protein complex is eluted from resin, it is separated by western blotting after high temperature deformation. The target protein antibody (anti- $\beta$-catenin) was used to detect the interaction with the bait protein. IgG antibody was used as a negative control to exclude nonspecific binding. Each experiment was repeated three times.

\section{Quantitative chromatin immunoprecipitation (qChIP)}

EZ-ChIP Kit (Millipore, Bedford, MA, USA) was used in fresh cells for ChIP experiments according to the method of the manufacturer's instructions. Five microgram of antiFXR antibody and $1 \mu \mathrm{g} \operatorname{IgG}$ negative control antibody were used to precipitate the chromatin-protein mixture, and finally amplified with specific primers (Supplementary Table S1) of the target fragment or endogenous noncoding region fragment and detected its expression using real-time quantitative PCR. The qRT-PCR condition adopted twostep method: pre-denaturation at $95{ }^{\circ} \mathrm{C}$ for $30 \mathrm{~s}$ followed by forty cycles of denaturation at $95^{\circ} \mathrm{C}$ for $5 \mathrm{~s}$ and extension at $60^{\circ} \mathrm{C}$ for $1 \mathrm{~min}$. The formula for calculating the enrichment index was $E^{\text {(Input Cq-ChIP Cq) }} / E^{\text {(Input Cq-Control Cq) }}$. Each experiment was repeated three times.

\section{Statistical analysis}

The differences among the experimental group and control group were compared by the Student's $t$-test or one-way ANOVA. All statistical results were done using the SPSS statistical package (SPSS Inc., Chicago, IL, USA). $P<0.05$ was considered as statistically significant.

\section{Results}

\section{$\beta$-Catenin level determines the varying responses of colon cancer cells to OCA}

The effect of FXR activation by OCA on the growth of six colon cancer cells was assessed by CCK8 assays. The results showed that RKO and HCT116 cells showed the most sensitivity to OCA with IC50 values of 0.9211 and $0.8377 \mu \mathrm{M}$, respectively, whereas DLD-1 and HT-29 cells were moderately resistant to OCA with IC50 values of 2.044 and $2.993 \mu \mathrm{M}$, respectively (Fig. 1a). However, SW403 and SW480 cells showed resistance to OCA with
IC50 values of 5.344 and $3.994 \mu \mathrm{M}$, respectively (Fig. 1a). SHP, the well-known target of FXR, has been proven to repress tumor growth by inducing apoptosis and cell cycle arrest [26]. As expected, after OCA exposure, RKO and HCT116 cells had dramatic changes in the mRNA and protein levels of $\mathrm{p} 21^{\mathrm{CIP} 1}$, cyclin D1, c-Myc, and SHP, whereas DLD-1 and HT-29 cells showed moderate changes (Fig. 1b-f and Supplementary Fig. 1a-d). However, SW403 and SW480 cells failed to show these changes (Fig. 1b-f and Supplementary Fig. 1a-d). We next evaluated the levels of FXR in six colon cancer cells in response to OCA exposure. Despite the fact that OCA increased the levels of FXR in colon cancer cells (Fig. 2a, b and Supplementary Fig. 1f), no correlation between FXR levels and OCA sensitivity was observed. OCA performs its function by expediting FXR nuclear translocation and occupancy of its target genes [27]. The results of IF assays indicated that RKO and HCT116 cells after OCA exposure had dramatic nuclear localization of FXR, whereas the other four cell lines treated with OCA exhibited moderate or low nuclear localization of FXR (Fig. 2c). From these observations, we inferred that there might exist contributing factors that influence the nuclear localization of FXR induced by OCA and thereby affect the antitumor effect of OCA.

SW403, SW480, DLD-1, and HT-29 cells have APC mutations, and HCT116 cells $\beta$-catenin mutations, whereas RKO cells have no Wnt/ $\beta$-catenin signaling-related mutations [28]. We reasonably questioned the correlation between the activity of Wnt//-catenin signaling and OCA sensitivity. However, we did not observe a correlation between TCF/LEF transcriptional activities and OCA sensitivity (Fig. 1g). Intriguingly, RKO and HCT116 cells, which were sensitive to OCA expressed low or no levels of $\beta$-catenin, while colon cancer cells resistant to OCA harbored high levels of $\beta$-catenin (Fig. 1h and Supplementary Fig. 1e). Among them, SW403 and SW480 cells had the highest expression of $\beta$-catenin. We inferred that $\beta$-catenin level might affect the antitumor effects of OCA on colon cancer cells.

\section{Loss of $\beta$-catenin sensitizes colon cancer cells to the antitumor effect of an FXR agonist}

We explored the detailed mechanism by which $\beta$-catenin regulates the antitumor effects of OCA. Deficiency of FXR resulted in sustained activation of the $\mathrm{Wnt} / \beta$-catenin pathway [29]. Firstly, we supposed whether there exists any physical interaction between $\beta$-catenin and FXR. IP of lysates with a $\beta$-catenin antibody demonstrated that FXR and $\beta$-catenin interacted with each other in colon cancer cells (Fig. 3a); moreover, this interaction was abolished upon $\beta$-catenin or FXR depletion (Fig. 3b, c).

We next hypothesized that $\beta$-catenin might affect FXR nuclear localization induced by OCA [30]. To confirm this 


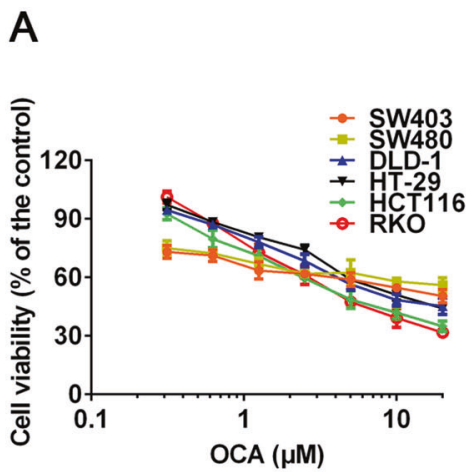

B

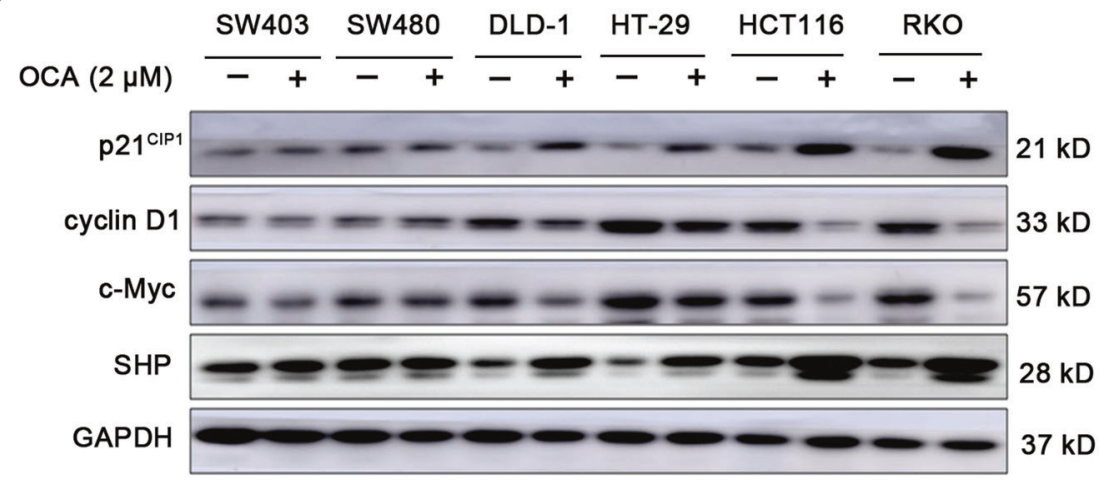

C
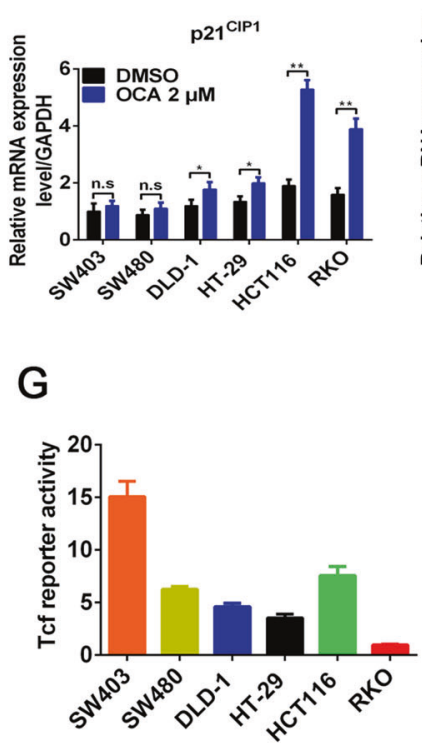

Fig. $1 \beta$-Catenin level determines the varying responses of colon cancer cells to OCA. a The effect of FXR agonist OCA on the viability of colon cancer cells SW403, SW480, DLD-1, HT-29, HCT116, and RKO detected by CCK8 assays. b The effect of OCA on the protein levels of $\mathrm{p} 21^{\mathrm{CIP} 1}$, cyclin D1, c-Myc, and SHP in colon cancer cells detected by western blotting analysis. $\mathbf{c}-\mathbf{f}$ The effect of OCA on

notion, we evaluated the effect of depleting $\beta$-catenin expression on FXR nuclear localization of SW403, SW480, DLD-1, and HT-29 cells treated with OCA. The IP assay showed that the OCA treatment induced the dissociation of the FXR/ $\beta$-catenin complex; notably, $\beta$-catenin depletion expanded this dissociation (Fig. 4a, b). Moreover, a marked elevation of nuclear FXR occurred in $\beta$-catenin-depleted cells as early as $2 \mathrm{~h}$ after OCA treatment, while a comparable elevation of nuclear FXR occurred in the control cells at $6 \mathrm{~h}$ (Fig. 4c-f), indicating that depletion of $\beta$-catenin accelerates FXR nuclear localization. As expected, depletion of $\beta$-catenin enhanced the binding of FXR to the SHP promoter after OCA treatment, as detected by the qChIP assay (Fig. 5a, b). Intriguingly, treatment with

$\mathrm{H}$
$\mathrm{E}$

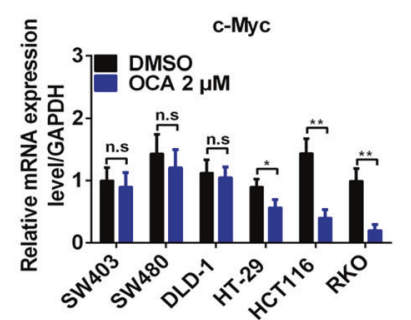

$\mathrm{F}$

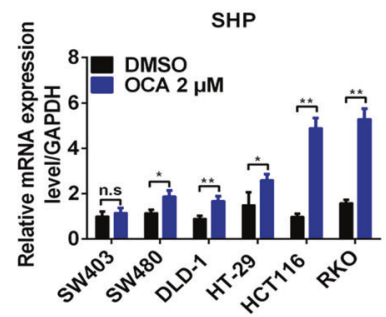

the mRNA levels of $\mathrm{p} 21^{\mathrm{CIP} 1}$, cyclin D1, c-Myc, and SHP in colon cancer cells detected by real-time PCR. $\mathbf{g}$ The effect of OCA on the luciferase activities of TOP/FOP-Flash reporter plasmid in colon cancer cells. $\mathbf{h}$ The expression of $\beta$-catenin in colon cancer cells detected by western blotting analysis. All data are the mean \pm SD of three independent experiments. $* P<0.05, * * P<0.01$.

ICG-001, an antagonist of $\beta$-catenin/TCF4-mediated transcription, did not induce occupancy of FXR on the SHP promoter (Fig. 5c); conversely, ICG-001 suppressed this occupancy. This is likely due to ICG-001 elevating the free pool of $\beta$-catenin [22]. These observations indicated that $\beta$-catenin levels but not its transcriptional activity affected the antitumor effects of OCA. Importantly, depletion of $\beta$-catenin enhanced the inhibitory effect of OCA on the growth of SW403, SW480, DLD-1, and HT-29 cells (Fig. 5d). Taken together, these data strongly suggest that depletion of $\beta$-catenin makes FXR amenable to earlier activation and accelerates FXR nuclear translocation and occupancy of its target genes, thereby enhancing the antitumor effect of OCA. 

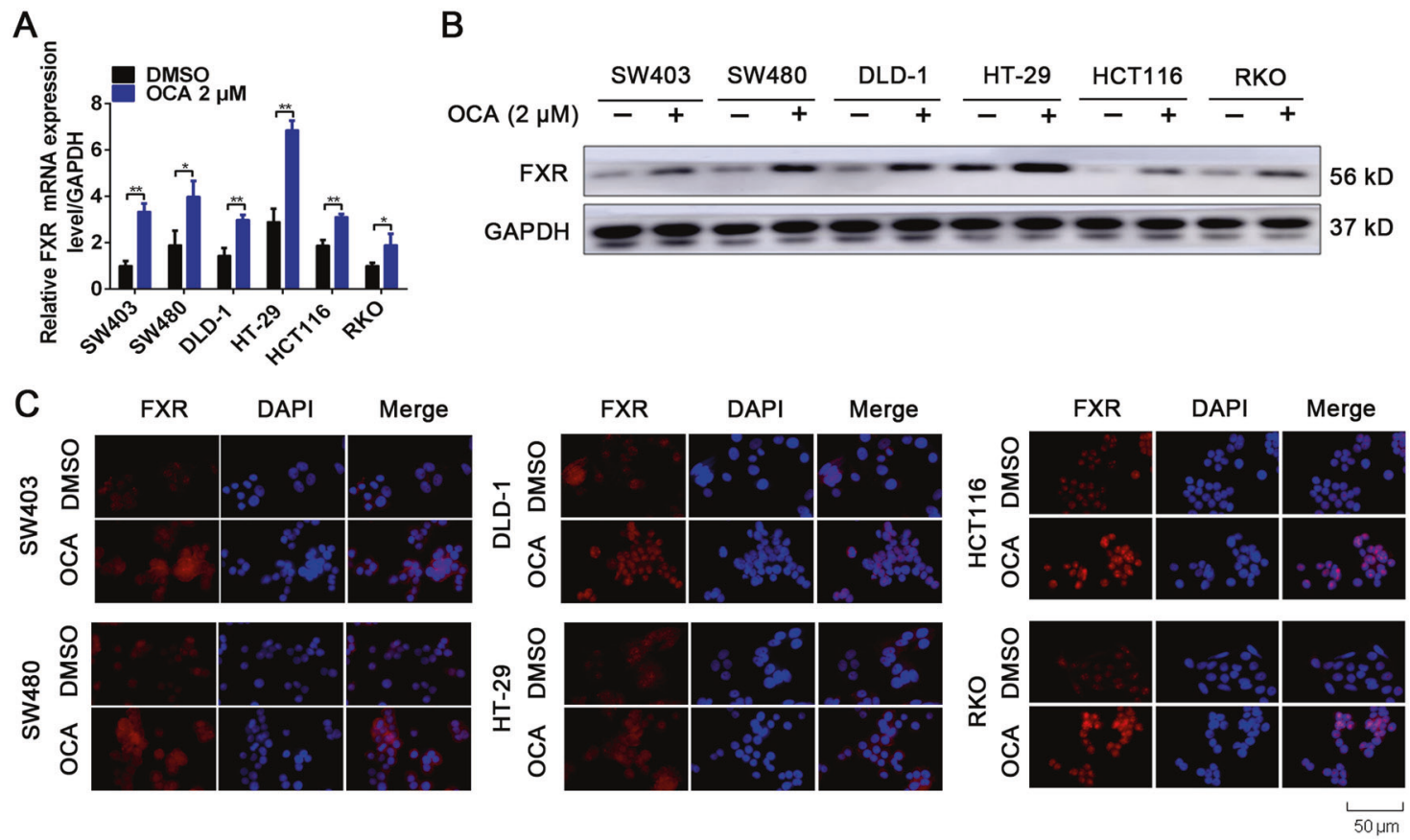

Fig. 2 OCA induced FXR activation in colon cancer cells. a The effect of OCA on the mRNA level of FXR in colon cancer cells detected by real-time PCR. b The effect of OCA on the protein level of FXR in colon cancer cells detected by western blotting analysis. c The effect of OCA on the nuclear translocation of FXR detected by IF staining. Scale bars, $50 \mu \mathrm{m}$. All data are the mean \pm SD of three independent experiments. $* P<0.05, * * P<0.01$.

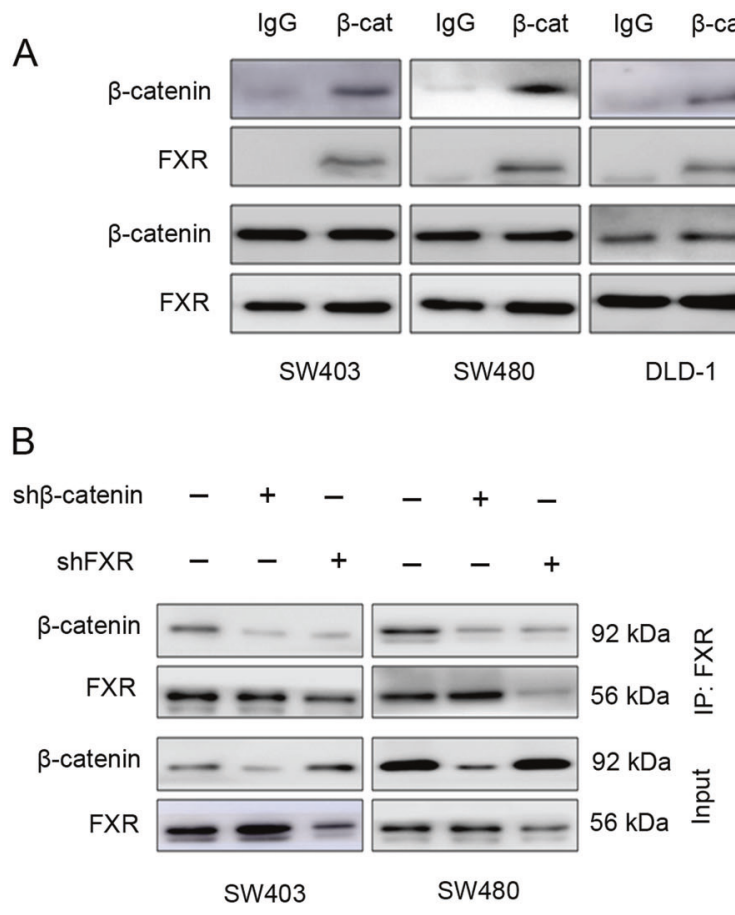

Fig. 3 Identification of $\mathbf{F X R} / \boldsymbol{\beta}$-catenin complex in colon cancer cells. a The physical interaction between FXR and $\beta$-catenin in colon cancer cells. The cell lysates were subjected to IP assay with an anti$\beta$-catenin antibody. $\mathbf{b}$ The depletion of $\beta$-catenin or FXR impaired the

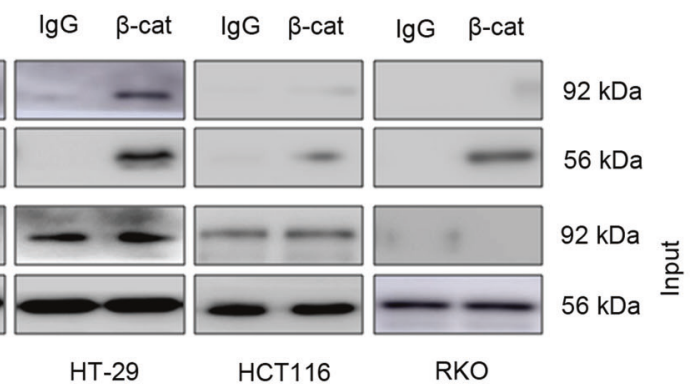

C

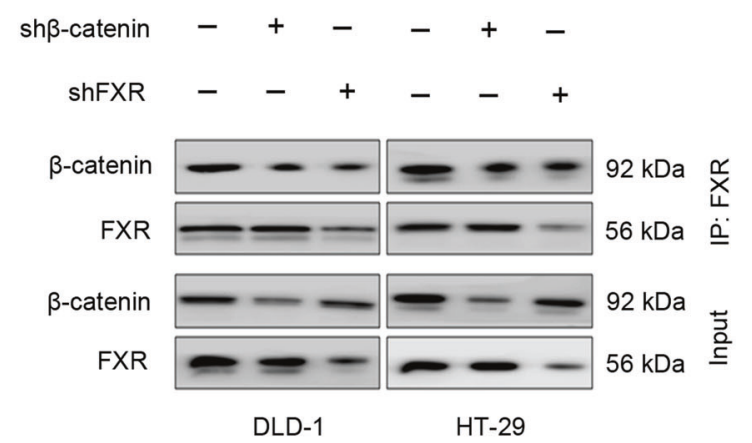

interaction of FXR and $\beta$-catenin in SW403 and SW480 cells. c The depletion of $\beta$-catenin or FXR impaired the interaction of FXR and $\beta$-catenin in DLD-1 and HT-29 cells. 

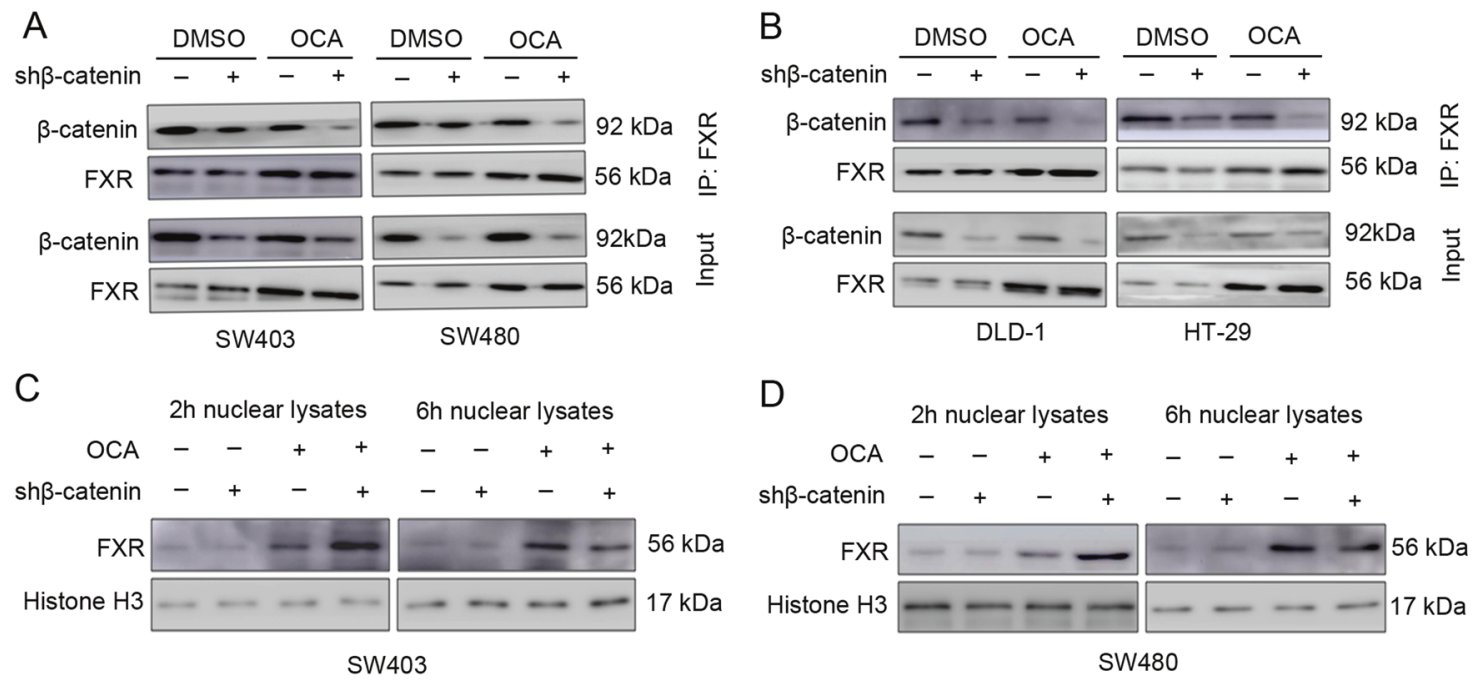

D
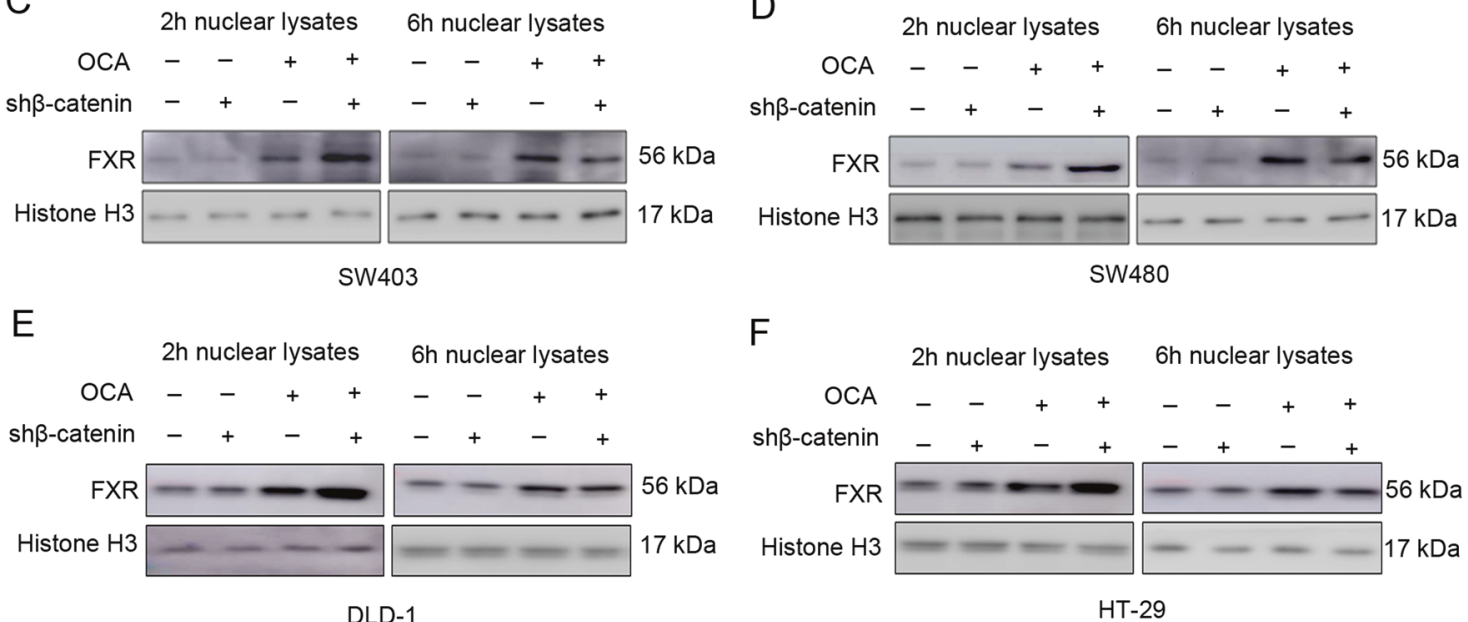

$\mathrm{F}$

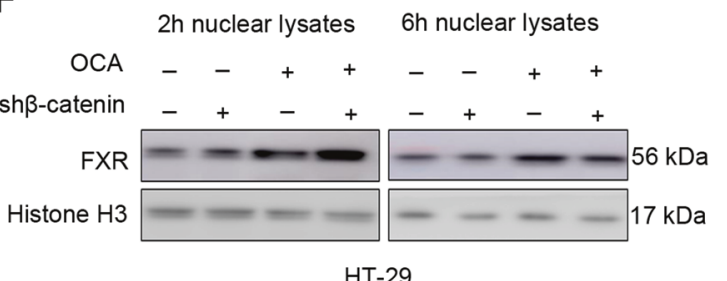

in DLD-1 and HT-29 cells detected by IP assays. c-f The effect of depleting $\beta$-catenin expression on the nuclear translocation of FXR in colon cancer cells treated with OCA detected by western blotting analysis. 作 SW480 cells detected by IP assays. b The effect of depleting $\beta$-catenin expression on the dissociation of FXR and $\beta$-catenin induced by OCA
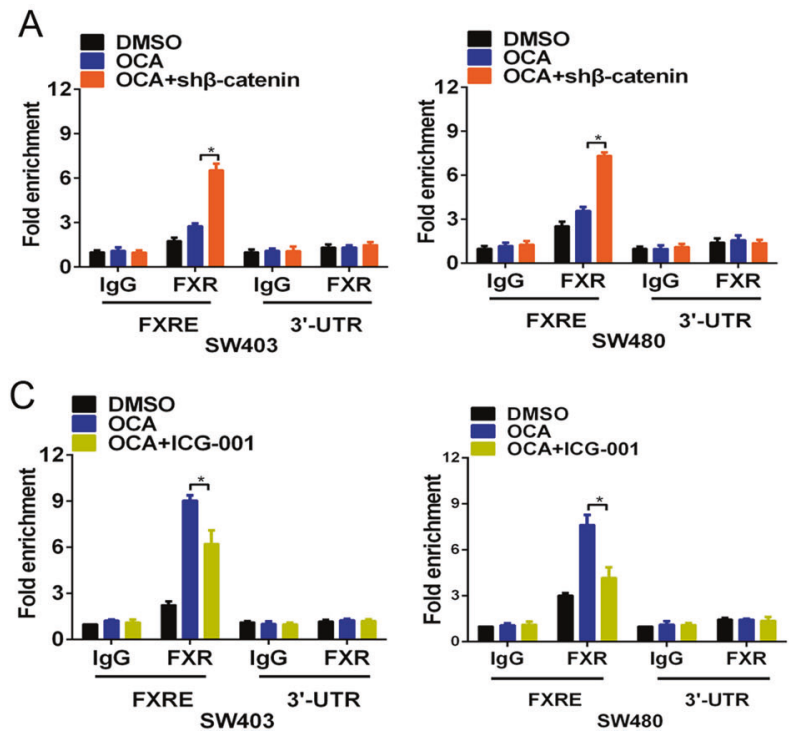

Fig. 5 Depletion of $\beta$-catenin affects the binding of FXR to SHP promoter induced by OCA. a, b The effect of depleting $\beta$-catenin expression on the binding of FXR protein to the SHP promoter in colon cancer cells detected by the qChIP assays. $\mathbf{c}$ The effect of ICG001, an antagonist of $\beta$-catenin/TCF4 complex, on the binding of FXR
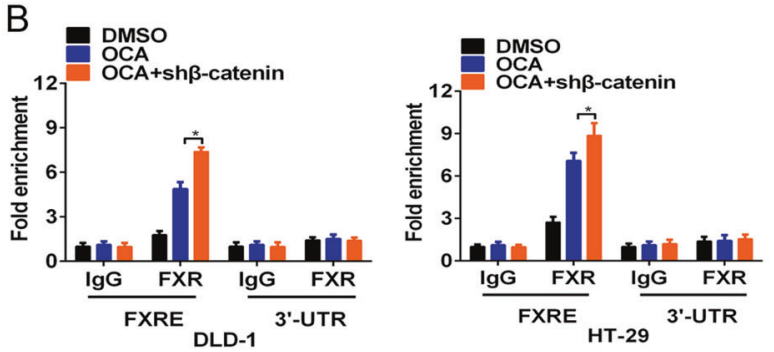

$\mathrm{D}$
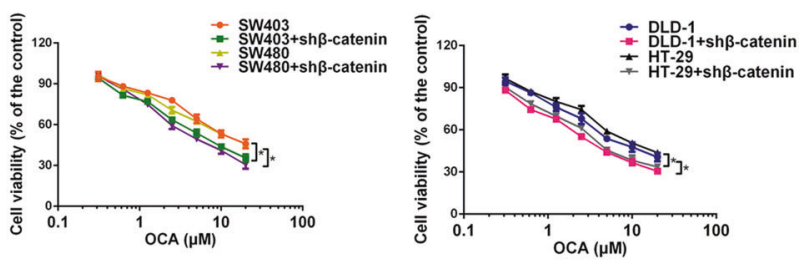

protein to the SHP promoter in colon cancer cells detected the qChIP assays. d The effect of depleting $\beta$-catenin expression on the viability of colon cancer cells detected by CCK8 assays. All data are the mean \pm $\mathrm{SD}$ of three independent experiments. $* P<0.05$, $* * P<0.01$. 

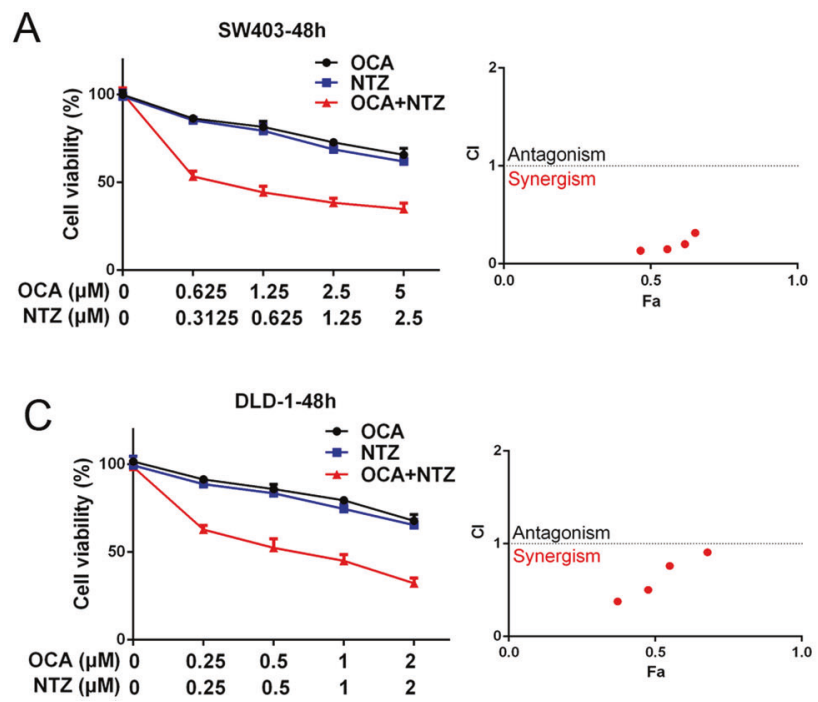

Fig. 6 Drug combination screen identifies NTZ acting synergistically with OCA in colon cancer cells. a-d Sensitivity of SW403, SW480, DLD-1, and HT-29 cells to OCA, NTZ alone, or OCA plus

\section{NTZ acts synergistically with OCA in colon cancer cells}

The above observations inspired us to reason that modulation of $\beta$-catenin by chemical agents could enhance the antitumor effect of OCA on colon cancer cells. We assessed drug combination synergism in vitro by measuring the average combination index $(\mathrm{CI})$ of OCA combined with the antiparasitic drug NTZ, which has been proven to abrogate $\beta$-catenin expression [31]. We first determined the IC50 values of NTZ in colon cancer cells. The results showed that NTZ inhibited the growth of SW403, SW480, DLD-1, and HT-29 cells with IC50 values of approximately 2.764, 2.294, 2.149, and $1.930 \mu \mathrm{M}$, respectively (Supplementary Fig. 2a). Moreover, NTZ caused dose-dependent repression of $\beta$-catenin expression in colon cancer cells (Supplementary Fig. 2c-f). Decreased $\beta$-catenin protein levels were followed by changes in the gene expression of the $\beta$-catenin downstream targets c-Myc and cyclin D1 (Supplementary Fig. 2b-f). These data indicated that NTZ inhibits the growth of colon cancer cells by abrogating $\beta$-catenin expression.

The average CI values indicated that the antiparasitic drug NTZ had strong synergistic effects with OCA on SW403, SW480, DLD-1, and HT-29 cells (Fig. 6a-d). Altogether, this evidence suggests that NTZ might enhance the efficacy of OCA against CRC.

\section{OCA and NTZ synergistically inhibit the tumorigenic properties of colon cancer cells in vitro}

By conducting a series of in vitro experiments, we evaluated whether NTZ enhanced the efficacy of OCA against CRC.
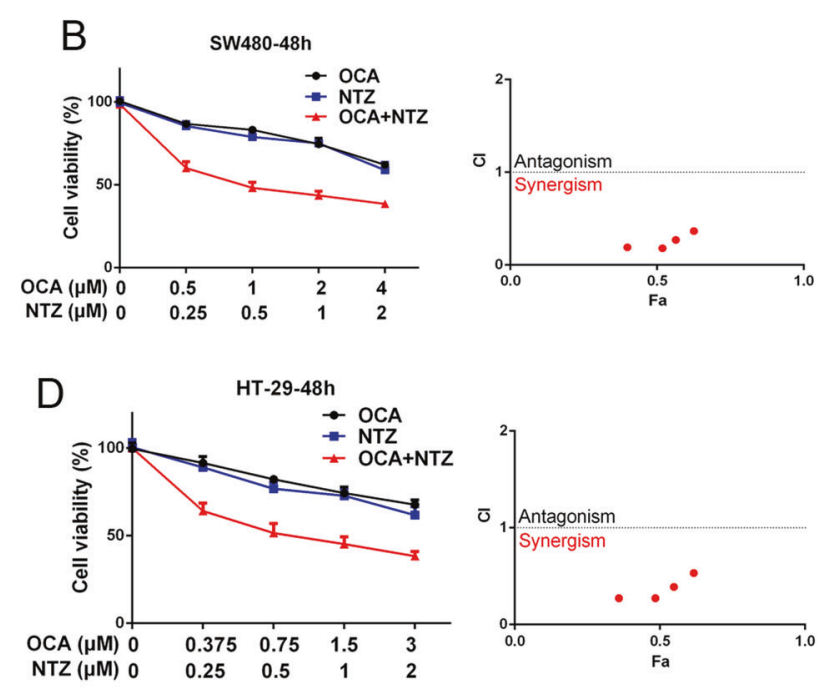

NTZ. Survival fraction (left) and the CI (right) are shown for each of these four cell lines. Fa fraction affected. Error bars represent means \pm SD.

SW403, SW480, DLD-1, and HT-29 cells were treated with OCA and NTZ alone or in combination. Compared to the single drug treatments, the combination of OCA and NTZ significantly repressed colony formation in colon cancer cells (Fig. 7a and Supplementary Fig. 3a). We further assessed the effects of combination therapy on cell cycle distribution and apoptosis by using flow cytometry. The combination of OCA and NTZ led to an increased percentage of cells in the G0/G1 phase and a decreased percentage in the $\mathrm{S}$ phase compared to the single drugs (Fig. $7 \mathrm{~b}$ and Supplementary Fig. 3b). Moreover, an increase in the apoptosis rate was observed in cells treated with OCA and NTZ in combination compared to that in cells treated with the single drugs (Fig. 7c and Supplementary Fig. 3c). In addition, the combination of OCA and NTZ dramatically suppressed the invasive ability of cells relative to the single drug treatments (Fig. 7d and Supplementary Fig. 3d). Consistent with the observations above, the combination therapy of OCA and NTZ significantly elevated SHP expression and altered cell cycle-related and invasionrelated proteins (Supplementary Fig. 4a-d). Altogether, this evidence suggests that NTZ enhances the efficacy of OCA in colon cancer cells.

\section{OCA and NTZ synergistically retard tumor growth in vivo}

To validate the synergistic effects of NTZ and OCA in vivo, we generated xenograft mouse models by injecting colon cancer cells subcutaneously into nude mice. The xenograft tumors in the OCA-treated and NTZ-treated groups developed much more slowly and were smaller and lighter than 

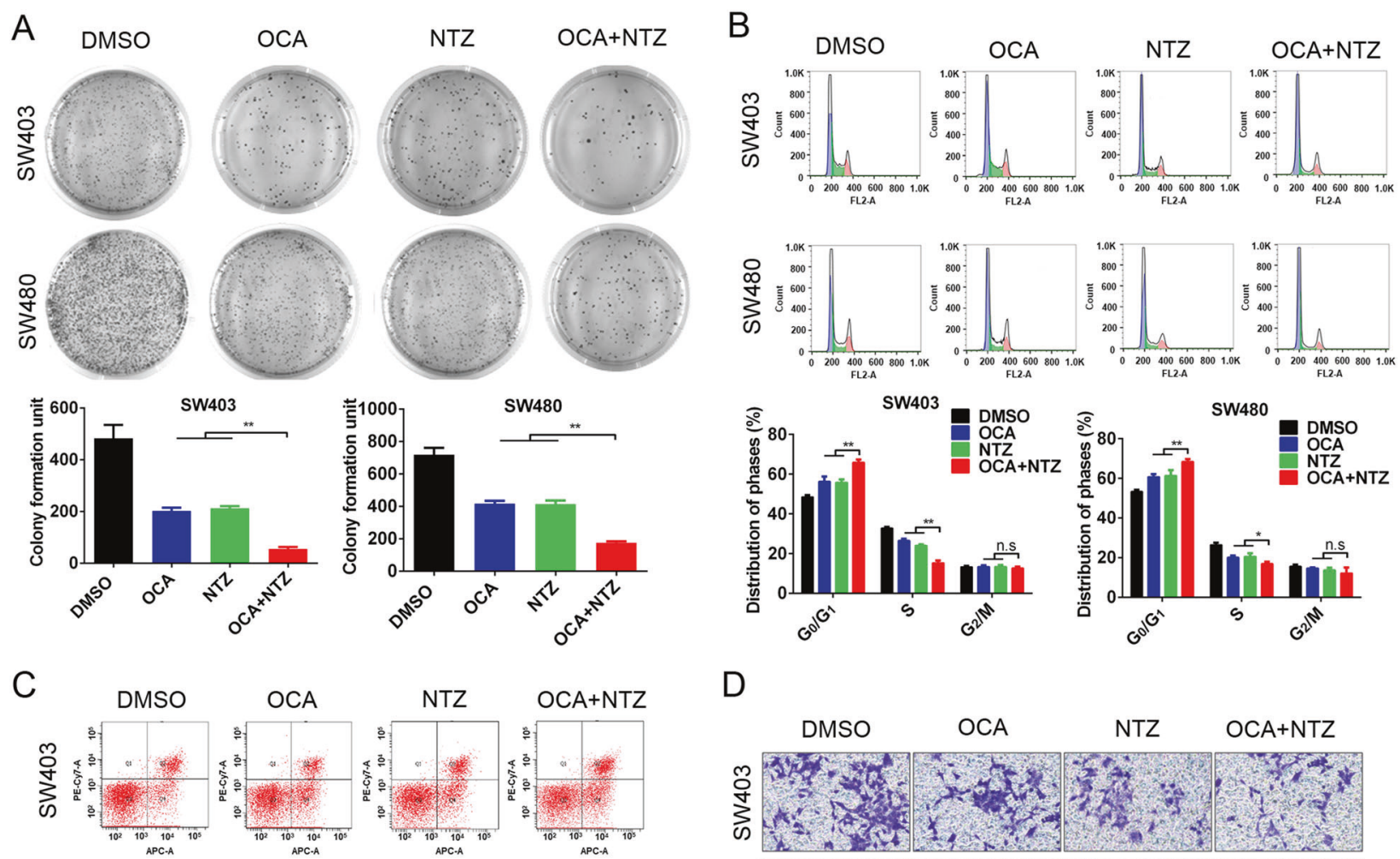

$\mathrm{D}$
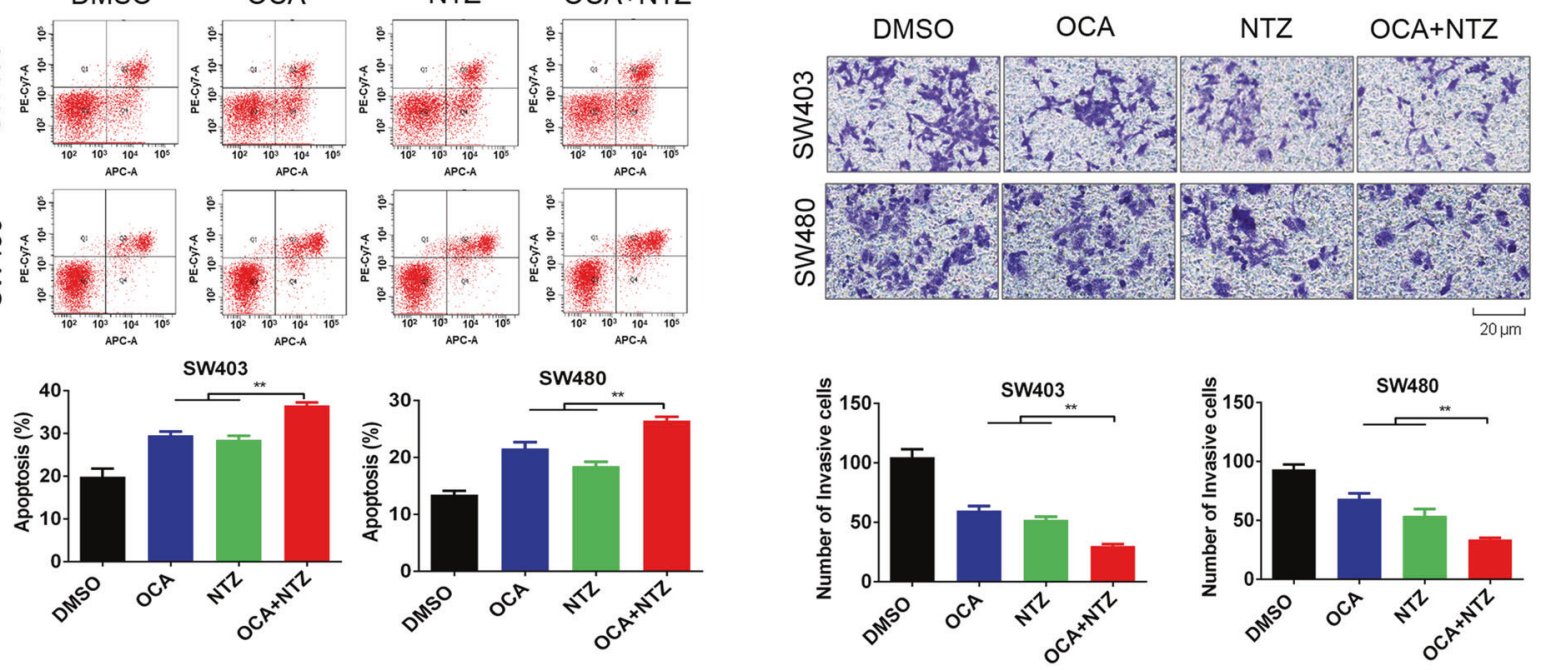

Fig. 7 OCA and NTZ synergistically inhibited the tumorigenic properties of colon cancer cells in vitro. a, b The effect of OCA, NTZ alone, or OCA plus NTZ on colony formation and cell cycle distribution of SW403 and SW480 cells. c, $\mathbf{d}$ The effect of OCA, NTZ alone or OCA plus NTZ on the apoptosis and invasion of SW403 and

those in the single drug-treated groups (Fig. 8a, b, d-f, h). According to $Q$ value method of Zhengjun jin [23] ( $Q$ value $>1.15$ was synergistic; $0.85-1.15$ was additive; $<0.85$ was antagonistic), $Q$ value for SW403 and SW480 xenografts is 1.19 and 1.22 , respectively, indicating that combination of OCA and NTZ have synergistical effect. Importantly, the combination therapy significantly lengthened progressionfree survival in relation to the single treatments (Fig. $8 \mathrm{c}, \mathrm{g}$ ). Mechanistically, the results from the IHC assay showed a stronger staining intensity of SHP, p21, E-cadherin, and active caspase- 3 and a weaker staining of c-Myc, cyclin D1, and MMP-2 in xenograft tumors treated with both agents than in those treated with a single agent (Fig. 8i, j).

SW480 cells. For SW403 cells, the concentrations of OCA and NTZ used were $1.25 \mu \mathrm{M}$ and $0.625 \mu \mathrm{M}$, respectively. For SW480 cells, the concentrations of OCA and NTZ used were $1 \mu \mathrm{M}$ and $0.5 \mu \mathrm{M}$, respectively. All data are the mean $\pm \mathrm{SD}$ of three independent experiments. $* P<0.05, * * P<0.01$.

In summary, these data suggested that OCA and NTZ can work synergistically to retard tumor growth in vivo.

\section{Discussion}

Chemotherapy is the second major treatment type for CRC after surgical treatment, but there are many problems with chemotherapy, such as drug resistance and side effects [32]. Thus, more effective strategies and novel targets for chemotherapy in this malignancy are urgently required. The tumor suppressive role of FXR in colorectal carcinogenesis has inspired us to restore FXR expression as a novel 
A

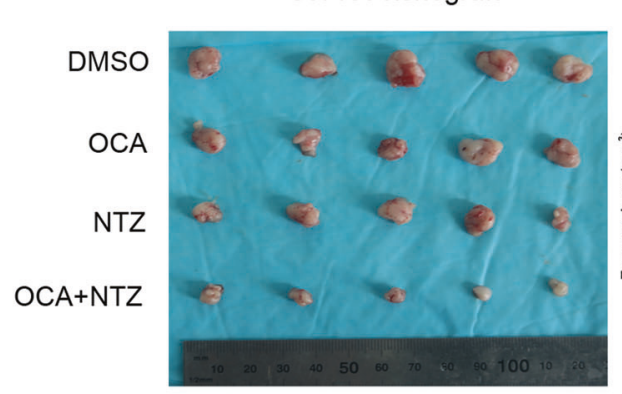

E

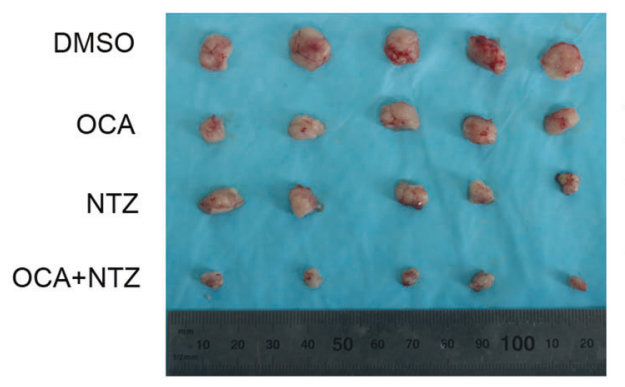

I

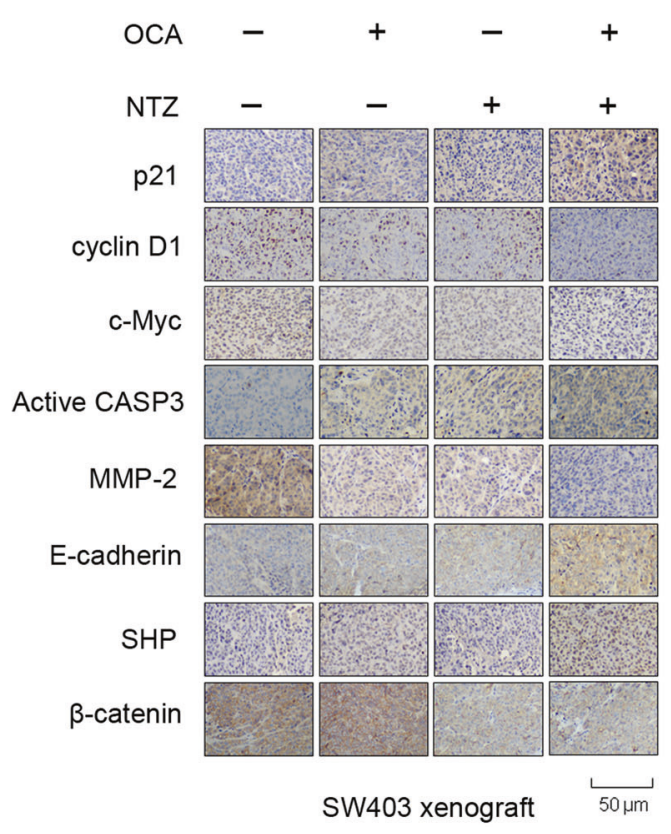

Fig. 8 OCA and NTZ synergistically retarded tumor growth in vivo. a Schematic representation of the tumor xenografts formed by SW403 cells treated with OCA, NTZ alone or OCA plus NTZ. b, d Tumor growth curves (b) and tumor weights (d) for tumor xenograft formed by SW403 cells after OCA, NTZ alone or OCA plus NTZ treatment. c Cumulative incidence plot displaying the percentage of tumors in each treatment group that has doubled in volume as a function of time. $\mathrm{P}$ values were calculated with log-rank test. e Schematic representation of the tumor xenografts formed by SW403

therapeutic strategy [17]. However, the complicated signaling network and tumor heterogeneity might hinder the effectiveness of FXR agonists in cancer treatment [22]. Our study
C
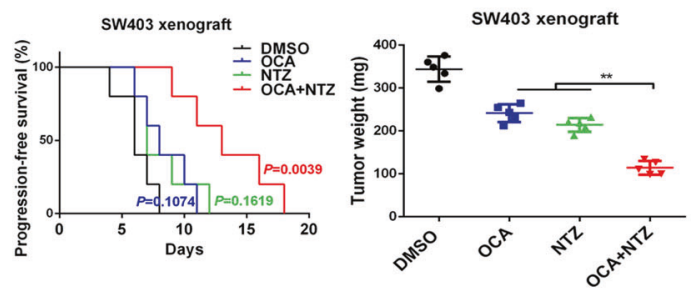

G

$\mathrm{H}$
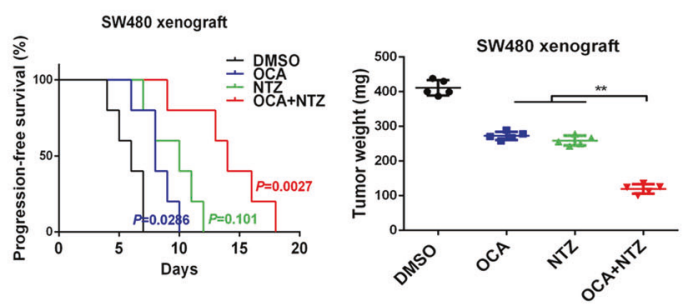

$J$

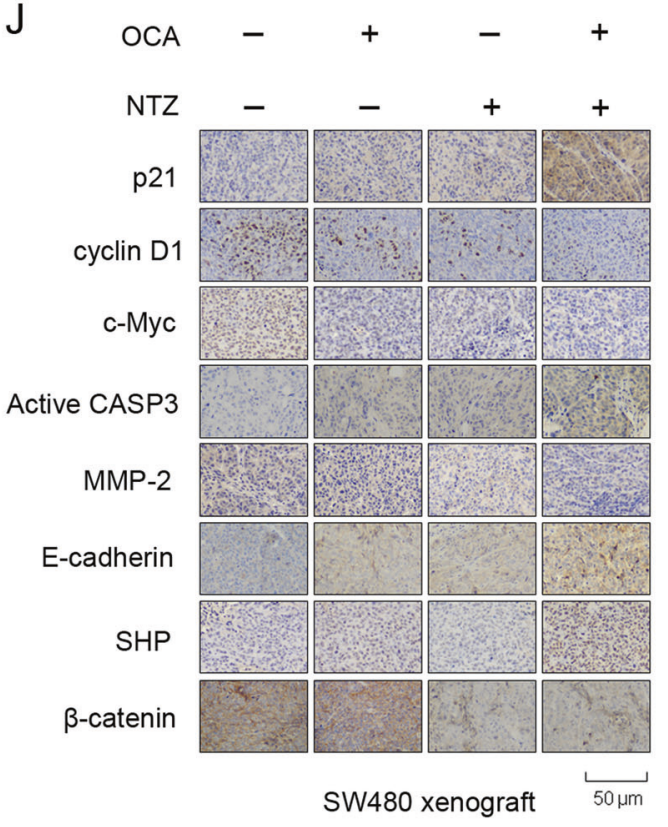

cells treated with OCA, NTZ alone or OCA plus NTZ. f, h Tumor growth curves (f) and tumor weights (h) for tumor xenograft formed by SW403 cells after OCA, NTZ alone or OCA plus NTZ treatment. g Cumulative incidence plot displaying the percentage of tumors in each treatment group that has doubled in volume as a function of time. $P$ values were calculated with log-rank test. $\mathbf{i}, \mathbf{j}$ IHC staining for $\mathrm{p} 21$, cyclin D1, c-Myc, active caspase-3, MMP-2, E-cadherin, and SHP in tumor xenografts formed by SW403 (i) and SW480 (j) cells. $* P<0.05, * * P<0.01$.

indicated that RKO and HCT116 cells that expressed no or low $\beta$-catenin were sensitive to OCA, whereas colon cancer cells harboring moderate or high levels of $\beta$-catenin were less 
sensitive or resistant to OCA. Notably, despite the increased FXR levels in all six colon cancer cells in response to OCA, only RKO and HCT116 cells had marked nuclear localization of FXR. We thus speculate that $\beta$-catenin might affect the localization of nuclear FXR induced by OCA, thereby antagonizing its antitumor effects. Subsequently, we identified a novel FXR/ $\beta$-catenin complex in colon cancer cells, which was previously confirmed by the work of Thompson et al in primary hepatocytes [22]. The FXR/ $\beta$-catenin complex might antagonize FXR nuclear localization and subsequent target gene transcription by FXR agonists [33]. As expected, depletion of $\beta$-catenin expedited FXR nuclear localization and enhanced its occupancy on the SHP promoter following OCA exposure. In HCC with $\beta$-catenin mutations [34], elevated $\beta$-catenin might sequester FXR and impair its ability to maintain bile acid homeostasis, which leads to intratumoral cholestasis. Intriguingly, activation of FXR blocked the Wnt/ $\beta$-catenin signaling pathway in HCC [29], indicating that there might exist a reciprocal relationship between FXR and $\beta$-catenin. Collectively, these novel findings identify an unrecognized role of $\beta$-catenin in colorectal carcinogenesis via sequestration of FXR and repression of its activity.

$\mathrm{Wnt} / \beta$-catenin signaling is one of the most promising targets for cancer chemotherapy, and a wide variety of Wnt inhibitors have been developed and are in the preclinical or clinical phase I stage [11]. Recently, the antiparasitic drug NTZ drew our attention. In contrast to previous Wnt inhibitors, NTZ antagonizes Wnt/ $\beta$-catenin signaling independent of GSK-3 $\beta$ and APC [31]. NTZ increased the citrullination and degradation of $\beta$-catenin by stabilizing PAD2. Our study demonstrated that NTZ repressed the growth of colon cancer cells by abrogating $\beta$-catenin expression. Notably, NTZ depleted $\beta$-catenin in colon cancer cells with mutant APC or $\beta$-catenin, For cancer treatment, a new use for an "old drug" has many benefits without the limitation of unknown safety and toxicity profiles [35]. Hence, NTZ is expected to be a potential anticancer drug for cancer patients with Wnt pathway mutations.

Monotargeted therapies are new treatment options that have begun to enter cancer treatment. However, due to complicated signaling networks and tumor heterogeneity, the effectiveness of these drugs is still unsatisfactory [36]. Recently, combination therapy has gathered tremendous interest with its ability to enhance efficacy and reduce side effects; for example, GW4064 combined with acyclic retinoid (ACR) exerted synergistic inhibitory effects on the growth of HCC with lower doses of both agents [37]. The depletion of $\beta$-catenin in colorectal carcinogenesis expedites FXR nuclear localization and FXR occupancy of target genes and thus offers a novel therapeutic opportunity. Herein, we identified the antiparasitic drug NTZ with synergism with OCA against CRC. This synergistic effect of OCA and NTZ was verified in a series of in vitro and in vivo experiments. Furthermore, our study revealed that this synergistic effect was probably attributed to elevated SHP expression. SHP has also been shown to suppress tumor cell proliferation and invasion via transcriptional repression of cyclin D1 and Ccl2 expression [26, 38]. However, we cannot completely rule out that other possible mechanisms might also account for the synergistic effects of OCA and NTZ against CRC. The activation of FXR by GW4064 has been proven to antagonize Wnt/ $\beta$-catenin signaling in HCC [29]. Hence, OCA may work synergistically with NTZ to repress the activity of Wnt/ $\beta$-catenin signaling.

The present study demonstrates that $\beta$-catenin affects the antitumor effects of OCA on colon cancer cells. Mechanistically, we identified an FXR/ $\beta$-catenin complex in colon cancer cells. Depletion of $\beta$-catenin accelerated the nuclear translocation of FXR and increased its occupancy of the SHP promoter in response to OCA treatment. Moreover, the combination of OCA plus the $\beta$-catenin inhibitor NTZ exerted synergistic tumor inhibition in CRC. Altogether, these findings offer useful evidence for the clinical use of FXR agonists combined with $\beta$-catenin inhibitors in combating CRC.

Acknowledgements This work was funded by a grant from the National Natural Science Foundation of China (Grant Serial Numbers: $81972720,81101874,81172362$ ), the Coordinative and Innovative Plan Projects of the Science and Technology Program in Shaanxi Province (Grant Serial Numbers: 2013KTCQ03-08), the Science and Technology Project of Shaanxi Province (Grant serial number: 2016SF-015, 2019SF-065), the Fundamental Research Funds for the Central Universities (Grant serial number: xjj2018123).

\section{Compliance with ethical standards}

Conflict of interest The authors declare that they have no conflict of interest.

Publisher's note Springer Nature remains neutral with regard to jurisdictional claims in published maps and institutional affiliations.

Open Access This article is licensed under a Creative Commons Attribution 4.0 International License, which permits use, sharing, adaptation, distribution and reproduction in any medium or format, as long as you give appropriate credit to the original author(s) and the source, provide a link to the Creative Commons license, and indicate if changes were made. The images or other third party material in this article are included in the article's Creative Commons license, unless indicated otherwise in a credit line to the material. If material is not included in the article's Creative Commons license and your intended use is not permitted by statutory regulation or exceeds the permitted use, you will need to obtain permission directly from the copyright holder. To view a copy of this license, visit http://creativecommons. org/licenses/by/4.0/.

\section{References}

1. Bray F, Ferlay J, Soerjomataram I, Siegel RL, Torre LA, Jemal A. Global cancer statistics 2018: GLOBOCAN estimates of incidence and mortality worldwide for 36 cancers in 185 countries. Cancer J. Clin. 2018;68:394-424. 
2. Coppede F, Lopomo A, Spisni R, Migliore L. Genetic and epigenetic biomarkers for diagnosis, prognosis and treatment of colorectal cancer. World J Gastroenterol. 2014;20:943-56.

3. Mei Z, Liu Y, Liu C, Cui A, Liang Z, Wang G, et al. Tumourinfiltrating inflammation and prognosis in colorectal cancer: systematic review and meta-analysis. $\mathrm{Br} \mathrm{J}$ Cancer. 2014;110: 1595-605.

4. Brenner H, Kloor M, Pox CP. Colorectal cancer. Lancet 2014;383:1490-502.

5. Vymetalkova V, Vodicka P, Vodenkova S, Alonso S, SchneiderStock R. DNA methylation and chromatin modifiers in colorectal cancer. Mol Asp Med. 2019;69:73-92.

6. Vaiopoulos AG, Kostakis ID, Koutsilieris M, Papavassiliou AG. Colorectal cancer stem cells. Stem Cells. 2012;30:363-71.

7. Rahmani F, Avan A, Hashemy SI, Hassanian SM. Role of Wnt/ $\beta$-catenin signaling regulatory microRNAs in the pathogenesis of colorectal cancer. J Cell Physiol. 2018;233:811-7.

8. Zhang L, Shay JW. Multiple roles of APC and its therapeutic implications in colorectal cancer. J Natl Cancer Inst. 2017;109: djw332.

9. Drost J, van Jaarsveld RH, Ponsioen B, Zimberlin C, van Boxtel $\mathrm{R}$, Buijs A, et al. Sequential cancer mutations in cultured human intestinal stem cells. Nature 2015;521:43-7.

10. Ghosh N, Hossain U, Mandal A, Sil PC. The Wnt signaling pathway: a potential therapeutic target against cancer. Ann N Y Acad Sci. 2019;1443:54-74.

11. Kahn M. Can we safely target the WNT pathway? Nat Rev Drug Discov. 2014;13:513-32.

12. Kandoth C, McLellan MD, Vandin F, Ye K, Niu B, Lu C, et al. Mutational landscape and significance across 12 major cancer types. Nature 2013;502:333-9.

13. Qu Y, Olsen JR, Yuan X, Cheng PF, Levesque MP, Brokstad KA. Small molecule promotes á-catenin citrullination and inhibits Wnt signaling in cancer. Nat Chem Biol. 2018;14:94-101.

14. Chavez-Talavera O, Tailleux A, Lefebvre P, Staels B. Bile acid control of metabolism and inflammation in obesity, type 2 diabetes, dyslipidemia, and nonalcoholic fatty liver disease. Gastroenterology 2017;152:1679-94.

15. Selmin OI, Fang C, Lyon AM, Doetschman TC, Thompson PA, Martinez JD, et al. Inactivation of adenomatous polyposis coli reduces bile acid/farnesoid $\mathrm{X}$ receptor expression through Fxr gene $\mathrm{CpG}$ methylation in mouse colon tumors and human colon cancer cells. J Nutr. 2016;146:236-42.

16. Maran RR, Thomas A, Roth M, Sheng Z, Esterly N, Pinson D, et al. Farnesoid $X$ receptor deficiency in mice leads to increased intestinal epithelial cell proliferation and tumor development. J Pharmacol Exp Ther. 2009;328:469-77.

17. Fu T, Coulter S, Yoshihara E, Oh TG, Fang S, Cayabyab F, et al. FXR regulates intestinal cancer stem cell proliferation. Cell 2019;176:1098-112.

18. Markham A, Keam SJ. Obeticholic acid: first global approval. Drugs 2016;76:1221-6.

19. Ali AH, Lindor KD. Obeticholic acid for the treatment of primary biliary cholangitis. Expert Opin Pharmacother. 2016;17:1809-15.

20. Erice O, Labiano I, Arbelaiz A, Santos-Laso A, Munoz-Garrido P, Jimenez-Aguero R, et al. Differential effects of FXR or TGR5 activation in cholangiocarcinoma progression. Biochim Biophys Acta. 2018;1864:1335-44.
21. Attia YM, Tawfiq RA, Ali AA, Elmazar MM. The FXR agonist, obeticholic acid, suppresses HCC proliferation \& metastasis: role of IL-6/STAT3 signalling pathway. Sci Rep. 2017;7:12502.

22. Thompson MD, Moghe A, Cornuet P, Marino R, Tian J, Wang P. et al. beta-Catenin regulation of farnesoid $\mathrm{X}$ receptor signaling and bile acid metabolism during murine cholestasis. Hepatology. 2018;67:955-71.

23. Jin ZJ. Addition in drug combination (author's transl). Acta Pharmacol. Sin. 1980;1:70-6.

24. Yu J, Li S, Qi J, Chen Z, Wu Y, Guo J, et al. Cleavage of GSDME by caspase-3 determines lobaplatin-induced pyroptosis in colon cancer cells. Cell Death Dis. 2019;10:193.

25. Livak KJ, Schmittgen TD. Analysis of relative gene expression data using real-time quantitative PCR and the 2(-Delta Delta $\mathrm{C}(\mathrm{T})$ ) method. Methods 2001;25:402-8.

26. Zhang Y, Xu P, Park K, Choi Y, Moore DD, Wang L. Orphan receptor small heterodimer partner suppresses tumorigenesis by modulating cyclin D1 expression and cellular proliferation. Hepatology. 2008;48:289-98.

27. Wang YD, Chen WD, Moore DD, Huang W. FXR: a metabolic regulator and cell protector. Cell Res. 2008;18:1087-95.

28. Tam BY, Chiu K, Chung H, Bossard C, Nguyen JD, Creger E, et al. The CLK inhibitor SM08502 induces anti-tumor activity and reduces Wnt pathway gene expression in gastrointestinal cancer models. Cancer Lett. 2020;473:186-97.

29. Wolfe A, Thomas A, Edwards G, Jaseja R, Guo GL, Apte U. Increased activation of the $\mathrm{Wnt} /$ beta-catenin pathway in spontaneous hepatocellular carcinoma observed in farnesoid $\mathrm{X}$ receptor knockout mice. J Pharmacol Exp Ther. 2011;338:12-21.

30. Zhang Y, Soto J, Park K, Viswanath G, Kuwada S, Abel ED, et al. Nuclear receptor SHP, a death receptor that targets mitochondria, induces apoptosis and inhibits tumor growth. Mol Cell Biol. 2010;30:1341-56.

31. Qu Y, Olsen JR, Yuan X, Cheng PF, Levesque MP, Brokstad KA. Small molecule promotes beta-catenin citrullination and inhibits Wnt signaling in cancer. Nat Chem Biol. 2018;14:94-101.

32. Gerhards NM, Rottenberg S. New tools for old drugs: functional genetic screens to optimize current chemotherapy. Drug Resist Updates. 2018;36:30-46.

33. Maloney PR, Parks DJ, Haffner CD, Fivush AM, Chandra G, Plunket KD, et al. Identification of a chemical tool for the orphan nuclear receptor FXR. J Med Chem. 2000;43:2971-4.

34. Audard V, Grimber G, Elie C, Radenen B, Audebourg A, Letourneur $\mathrm{F}$, et al. Cholestasis is a marker for hepatocellular carcinomas displaying beta-catenin mutations. J Pathol. 2007;212: 345-52.

35. Bertolini F, Sukhatme VP, Bouche G. Drug repurposing in oncology-patient and health systems opportunities. Nat Rev Clin Oncol. 2015;12:732-42.

36. Finn RS. Emerging targeted strategies in advanced hepatocellular carcinoma. Semin Liver Dis. 2013;33:S11-S9.

37. Ohno T, Shirakami Y, Shimizu M, Kubota M, Sakai H, Yasuda Y, et al. Synergistic growth inhibition of human hepatocellular carcinoma cells by acyclic retinoid and GW4064, a farnesoid X receptor ligand. Cancer Lett. 2012;323:215-22.

38. Yang Z, Koehler AN, Wang L. A novel small molecule activator of nuclear receptor SHP inhibits HCC cell migration via suppressing Ccl2. Mol Cancer Ther. 2016;15:2294-301. 